\title{
THE REGULATION OF MOTOR CARRIERS IN PENNSYLVANIA*
}

The history of transportation in Pennsylvania divides itself into several periods, each period characterized by primary reliance put upon some particular agency of transportation. First, there were the roads, highways and turnpikes; then the period of canals; next came the dominance of the railroads and street railways. And within recent years there is promise of a new period: that of motor carriers operating as public carriers on a huge scale, effecting a return of the highway to its former hegemony.

In the earliest period, reliance was placed primarily upon bridle paths which followed the Indian trails, and which were subsequently developed into wagon roads. The rivers were navigated only by small craft, and crossed by infrequent ferries and bridges. During colonial times a few important roads, chiefly military highways, were built, crossing the Alleghenies into the wilderness, to Fort Duquesne. ${ }^{1}$ The construction of important turnpikes engaged the interest of Pennsylvania almost exclusively from $I 792$ until $I 822$, the period culminating between 1830 and 1840 . The first, the Philadelphia and Lancaster Turnpike, ${ }^{2}$ was immediately followed by over one hundred others. The country's most important early national road, the Cumberland Road, was in reality a Pennsylvania road, since out of a total of II2 miles in its first section, $75 \mathrm{I} / 2$ miles were in Pennsylvania. ${ }^{3}$

*The material of the following article was collected in a comprehensive study by the writers of public utility regulation in Pennsylvania as well as in other states which will be published within the year.

${ }^{2}$ Braddock's Road was built in 1755 ; Forbes' Road in 1758.

2 This road, sixty-two miles in length, was completed in 1792.

${ }^{3}$ This highway, begun by the United States Government in I8II, extended West from Cumberland through Maryland, Pennsylvania and Virginia to what was later Wheeling, the first great artery to the West. It was extensively used for commercial transportation, with lines of stage coaches and wagoners. The cost of transportation, however, continued high in spite of this road, so that even in I8I7 it cost $\$ 100.00$ per ton to transport goods from Philadelphia to Pittsburgh; if the roads were good, a stage coach could go from Philadelphia to Pittsburgh, about 350 miles, in three days. 
Next came the canals. Pennsylvania was the first state to undertake a comprehensive canal project. In I762 a survey was made for a canal to connect the Schuylkill and Susquehanna Rivers, and in I793 the legislature authorized the Conewago Canal in York County, which was completed in $1797 . .^{4}$ Beginning in 1826 and continuing until 1840 , when the work was stopped by the success of the railroads, Pennsylvania was the scene of extensive internal improvements, emphasizing canals and the building of locks for canals. While the Erie Canal of New York is more frequently heard of, the fact is that the Pennsylvania Canal, from Philadelphia to Pittsburgh, together with its connecting rivers, was longer than the Erie Canal and cut through more difficult country.

The impetus toward railroads, which did not take long to relegate the canals to a position of secondary importance, began about I83o. The Philadelphia and Reading Railroad was chartered in 1833 and the Pennsylvania Railroad in I846. There had, before this time, been a few railroads in operation, but of a very crude sort. Probably the first, a gravity road, was that operated by the Lehigh Coal and Navigation Company from Mauch Chunk to its mines nine miles distant. The state itself built railroads, such as that from Philadelphia to Columbia, and from Hollidaysburg to Johnstown. Since large sums from the public treasury had been put into the canal system, many citizens looked with apprehension upon the progress of railroads. In $183 \mathrm{I}$ the Board of Canal Commissioners, to reassure these people, made the following interesting statement:

"While the Board avow themselves favorable to railroads where it is impracticable to construct canals, or under some peculiar circumstances, yet they cannot forbear to explain their opinion that the advocates of railroads generally have greatly overstated their commercial value. To counteract the wild speculations of visionary men and to allay the honest fears and prejudices of many of our best citizens who have been induced to believe that railroads are better than

In I79I it chartered the Schuylkill and Susquehanna Navigation Company, which later consolidated with other companies to become the Union Canal Company, with a total of 108 miles under operation. 
canals . . . the Canal Commissioners deemed it to be their duty to state a few facts which would exhibit the comparative value of the two modes of improvement. . . . It will be found that canals are from two to two and one-half times better than railroads for the purposes required of them." 5

By I850 railroad mileage in Pennsylvania had passed the thousand mark, and from that time forward the leadership of the railroad was unquestioned. Pennsylvania is today one of the leading railroad states of the union.

Along with these developments there was a very interesting movement in municipal transportation. In the period of the '80's street railways were being developed and were entering into competition with horse-drawn omnibus lines. ${ }^{6}$ It did not take this newer method of carriage long to supersede the omnibus line and shortly thereafter the motor vehicle appeared and threatened the ascendency of the street railway. As early as 1903 we find the following comment by a legal reporter:

"While omnibus lines have been almost entirely superseded on the streets of cities by street railways, it is possible that the recent invention of horseless omnibuses propelled by gasoline or electricity may make the subject of practical importance in the near future." 7

True to this prediction, we did about a decade ago have the sporadic jitney bus period and the commencing of the present system of automobile carriage by motor bus and truck. It is more than a century since the highway lost its supremacy to the canal, the railroad and the street railway. It is interesting to observe that in the past five years, as a medium for the motor bus and truck, it is returning to a place of outstanding importance in the transportation system. Recent surveys indicate that the highways of the country have already surpassed the railroad as a chief

\footnotetext{
'Swank, Progresstve Pennsylvania (Ig08) 158-159.

- For discussion of competition of omnibuses and street railways as an insufficient reason for refusing to license a street railway under discretionary power, see Comm. v. Baldwin, I4 Phila. 93 (I880).

${ }^{7}$ I7 P. \& L. Dig. Col. 29736.
} 
means of passenger transportation $;^{8}$ and the phenomenal building of improved highways in Pennsylvania has accelerated this movement. ${ }^{9}$

The Pennsylvania Public Service Commission was one of the first commissions in the country to assume wide regulatory powers over motor carriers. Jurisdiction was assumed as early as I9I4 under the act creating the body and giving it general power to regulate common carriers and public utilities. ${ }^{10}$ Most states, particularly during the last five years, have passed comprehensive statutes delegating the power of regulation over motor carriers to similar commissions and defining the rights and duties of motor carriers. ${ }^{11}$ Pennsylvania, however, has avoided such a new act or amendment to its old act; its commission still regulates motor carriers under the original law. Nowhere does this specifically mention motor carriers, but speaks entirely of common carriers and their obligations. Automobiles operating as common carriers have been construed to fall within the definition of common carriers, have been required to obtain certificates of convenience and have been subjected to the appropriate regulative features of the act. ${ }^{12}$

The term "public service company" is defined by Article I,

${ }^{8}$ See Henry R. Trumbower, Economics of Highway Transportation, 3 I Journal of THE Western SOCIETY OF ENGINEERS, No. 4 (1926).

- Since 1917, and until July I, 1926, Pennsylvania completed I,I88 miles of highway with Federal Aid, at a total cost of $\$ 6 \mathrm{I}, 360,150.80$, of which the Federal government contributed $\$ 21,560,732.04$. A total of 597.2 miles are now under construction and an additional 59 miles approved for construction with a balance in the Federal Aid Fund of $\$ 286,788.42$ available for new projects. From 7 Public Roads, No. io (Dec., I926).

The facts relied upon in the foregoing are derived from the following: Swank, Progressive Pennsylvania (1908); TanNer, Description of the Canals and Railroads of the United States ( 1840 ); Meyer \& MacGind, History of Transportation IN THE United STATES Before I860; Ringwalt, TRANSPORTATION IN THE UNited States (1888); 2 I ENCYCLOPEDIA BritaNNrCA I68.

${ }^{30}$ Act of I9I3, P. L. I374, Pa. STat. (1920) § $1805 \%$.

"Iilientha1 \& Rosenbaum, Motor Carriers and the State: A Study in Contemporary Public Utility Legislation, 2 Journal of LAND aNd PUBLIC UTILITY ECoNomics 257.

"See cases discussed in the next section herein. Taxicabs have been held common carriers, Connelly v. R. R., 53 Pa. Super. 78 (I9I3) ; Kerr v. R. R., 53 $\mathrm{Pa}$. Super. 83 (IgI3). A taxicab has been held a "public conveyance provided for passenger service, and propelled by gasoline" within the terms of an accident insurance policy. Primrose v. Casualty Co., 232 Pa. 2I0, 8I Atl. 2 I2 (IgII). 
Section I, as including. "all common carriers," and this section then proceeds to define common carrier as follows:

"The term 'common carrier,' as used in this act, includes any and all common carriers, whether corporations or persons, engaged for profit in the conveyance of passengers or property, or both, between points within this Commonwealth, by, through, over, above, or under land or water, or both."

And Article III, Section 2 (b), requires the approval of the Commission, as evidenced by a certificate of public convenience, for any public service company "to begin the exercise of any" right, power, franchise or privilege in any ordinance, municipal contract, or otherwise." Construing these two sections together, the Commission has held that before a common carrier can lawfully operate motor cars over the roads of Pennsylvania, it must obtain a certificate of public convenience from the Commission. ${ }^{13}$ Of course, by the same reasoning motor carriers are subjected to all the other duties and obligations and are entitled to all the rights set forth in the act applicable to their operation: for example, they must, under Article III, Section 2 (a), obtain a certificate of public convenience for their incorporation, ${ }^{14}$ and they are subject to rate regulation by the Commission. ${ }^{15}$

It is clear that under the act, the Commission has jurisdiction over only common, and not private carriers. Accordingly, it has been held that a foreign corporation authorized by its charter to engage in a common carriage may register in Pennsylvania for the purpose of engaging in private carriage alone and need not obtain the approval of the Commission for such operation. ${ }^{16}$

${ }^{13}$ Scranton R. R. v. Walsh, C. D. 44 I (I915), II Pa. P. S. C. R. 262; Huffman $e t$ al. v. Rue, C. D. 5788 (I924), VI Pa. P.S. C. R. 682; Fullington Auto Bus v. Hugh Milligan et al., C. D. 2875 (I9I8), IV Pa. P. S. C. R. 76.

${ }^{14}$ Fagen et al v. Pitts. Traction Co., C. D. 2849 (I9I8), III Pa. P. S. C. R. 65. See Rules of Practice Before PA. P. S. C. (I9I4), Rule 24, for statement of corporate purposes required for issuance of certificate approving incorporation of taxicab companies and auto transportation companies.

C. R. 311 .

${ }^{15}$ See, for example, In re John M. Drew, A. D. 3405 (I92I), V Pa. P. S.

${ }^{16}$ Application of Philadelphia and N. Y. Transportation Co., A. D. 9734 (1924), VI Pa. P. S. C. R. 808. 
However, it is not always a simple matter to determine if a particular motor carrier is a common carrier or not. The test itself of common carriage is simple enough-a carrier holding itself out to serve any member of the public for compensation-but in the many complex situations that arise it is often debatable if there is a "holding out."

A review of the cases passed on by the Commission and the courts is enlightening. ${ }^{17}$ In Howard v. Public Service Commission, a motor car used to convey daily employees of a factory from a borough to and from the factory, which factory was located near one of its termini, and collecting equal fares from all of those who presented themselves, was held to be a common carrier. ${ }^{18}$ And in Spontak v. Public Service Commission, ${ }^{19}$ an operator used a taxicab between certain towns, making five or six trips a day at a uniform charge and carrying all up to the limit of its capacity. Despite the fact that he did not operate constantly, he was held a common carrier. Similarly, where there was evidence that an operator used a taxicab in soliciting passengers at a railroad station and gave receipts for money paid as "taxi service" and "fares," the Commission's finding that he was operating as a common carrier was sustained..$^{20}$ Again, in the case of an operator who kept his two vehicles standing in the street near a railway station, accepting for carriage all persons who applied, and who in this way filled his cars even if he had previously arranged to meet a particular party, there was held evidence sufficient to warrant a finding of common carriage. ${ }^{21}$ Other types of common carriers regulated are automobiles used

${ }^{17}$ Taxicabs as common carriers, Connelly v. R. R., and Kerr v. R. R., supra note I2. Moving vans as common carriers, Lloyd v. Hough \& Keenan Storage \& Transfer Co., 223 Pa. 148, 72 Atl. 516 (I909).

${ }^{18} 77 \mathrm{~Pa}$. Super. 188 (I921). For a similar case where the carrier purported to have "regular" customers, see Kendig v. Schwartz, C. D. 5728 (I923), VI Pa. P. S. C. R. 569; Wayne Transp. Co. v. Leopold, C. D. 5822, 5823 (Ig23), VI Pa. P. S. C. R. 575 .

${ }^{10} 73 \mathrm{~Pa}$. Super. 219 (I919).

${ }^{20}$ Adams v. P. S. C., 77 Pa. Super. 38I (I92I).

${ }^{21}$ Domiani v. P. S. C., 73 Pa. Super. 37 (IgI9). 
on tourists' trips or sightseeing tours, ${ }^{22}$ and cars engaged in jitney service. $^{23}$

In order to make out a case of common carriage, there must be operation of the vehicle as a business and for hire. If no compensation is paid for the service, there can be no common carriage. Thus in Shaw $v$. Smith, ${ }^{24}$ where several owners of automobiles agreed among themselves to alternate weekly in the use of a car of one of their number to take them to and from work, and made no charge or division of expense, there was held to be no common carriage. Likewise, operation under a private contract without any holding out to the public would prevent a carrier from being classified as a public carrier. Service limited to funerals, weddings and similar occasions are illustrations. ${ }^{25}$ Transportation of children under contract with school authorities is private carriage and not within the jurisdiction of the Commission. ${ }^{26}$ However the mere fact of having a private contract can not be used as an excuse to convert one who is in reality a public carrier into a private one, ${ }^{27}$ and so, if all the elements of common carriage are present, the mere existence of such a contract does not change the status of a carrier..$^{28}$ Nor will the subterfuges employed at times by so-called "community buses" which

22 In re Application of the Alvin R. Bush, A. D. II304 (1924), Pa. P. S. C., No. I499; Plank v. Gilbert, C. D. 53 II (1923), VI P. S. C. R. I83 (Guide on Gettysburg Battlefield).

${ }^{23}$ Scranton R. R. v. Walsh, supra note 13; So. Pa. Traction Co. v. Kane, C. D. 3825 (I92I), V Pa. P. S. C. R. 76.

${ }^{24}$ C. D. 6229 through $604 \mathrm{I}$ (1924), Pa. P. S. C. No. I48r.

${ }^{25}$ Halperin v. P. S. C., 81 Pa. Super. 59I (I923) ; Application of Wm. H. Jones, A. D. 9066 (1923), VI P. S. C. R. 549 ; see Application of Philadelphia R. \& Co., C. D. 3II2 (1925), Pa. P. S. C. No. I589.

${ }^{2}$ Huffman v. Rue, supra note I3. note 18.

${ }^{27}$ Wayne Transportation Co. v. Leopold, and Kendig v. Schwartz, supra

${ }^{28}$ Wilkes-Barre Ry. v. Hartman, C. D. 6434 (1925), Pa. P. S. C. No. 155I. In this case it was held that bus service rendered to the employees of an industry daily, for which the employees paid seven cents a ride, is not divested of its character as a common carrier by the acceptance of an agreement or lease made with the manager of the mill for the daily operation of the buses. Further, where a motor carrier, besides transporting goods under a contract, does hauling for others, he is rendered thereby a common carrier, e. g., a motor carrier who transports goods under a. contract with an association composed of forty-four members and besides does hauling for others. Buffalo and Lake Erie Traction Co. v. Henneous, C. D. 5712 (I923), VI Pa. P. S. C. R. 584; Henneous v. Henneous, C. D. 5556 (1923), VI Pa. P. S. C. R. 505. 
purport to operate for the benefit of some community and accept fare in the guise of "contributions," or make a "gift" of tickets on the payment of a certain sum, remove operation, otherwise common carriage, from that classification. ${ }^{29}$

In certain instances the finding of the Commission that a carrier was operating as a common carrier has been reversed by the court. Such has been the case where the only evidence that the defendant was operating as a common carrier was that people had sometimes paid for being carried in his auto; but defendant had not stood in the street, had not solicited patronage, nor held himself out for transportation of the public. ${ }^{30}$ And again the finding of the Commission has been reversed where the only testimony was that of the complainant who saw the defendant take passengers in his auto between certain towns, take money and solicit return passengers, but did not know whether the original passengers were solicited or specially contracted with, whether a regular fare was charged, and whether return passengers were ever actually carried. ${ }^{31}$ In Ramsey \& Johnson v. Public Service Commission, ${ }^{32}$ where it appeared that the owner of a vehicle had not actually operated it himself, but some other person, not under his authority or in his employ, had done so, the order of the Commission directed against the owner was reversed.

The jurisdiction of the Commission has been extended to motor carriers operating whether over regular or irregular routes, or between definite or indefinite termini. The phrase in Article I, Section I, of the Act, limiting jurisdiction of the Commission to common carriage "between points within this Commonwealth," is held not to limit the jurisdiction of the Commission to motor service rendered along definite routes and between designated points. ${ }^{33}$ And further, it is given control over both

20high Valley Transit Co. v. Bander et al., C. D. 480 (I92I), V Pa. P. S. C. R. 309; York Ry. v. Longstreet, C. D. 5833 (1924), VI Pa. P. S. C. R. 7Ir.

${ }^{30}$ Ramsey \& Johnson v. P. S. C., 73 Pa. Super. 215 (I9I9).

"Toth v. P. S. C., 73 Pa. Super. 217 (I9I9). But held otherwise where these facts were proved: Piercely v. P. S. C., 73 Pa. Super. 2 I2 (I9I9).

Supra note 3o. See also, Smith v. P. S. C., 73 Pa. Super. 209 (Igrg).

${ }^{*}$ So. Pa. Traction Co. v. Kane, supra note 23 . 
intercity motor operation and operation entirely within the limits of a municipality. It has exclusive power to issue certificates of public convenience and necessity and to determine that there shall or shall not be operation within a municipality, and, therefore, power to issue a certificate without requiring the applicant to secure a franchise or consent for operation from a municipality in which it is to operate. The power to prohibit service which is necessary for the public convenience rests solely with the Commission. It is a matter over which municipalities have no control. ${ }^{34}$

Nevertheless municipalities still have a large measure of control over motor carriage. By acts of I9I3, I9I5 and I925, they have been given power to regulate, license, prescribe rates for, and designate streets for operation of motor vehicles operating "within the limits of the city or from points in the city to points beyond the city limits." ${ }^{35}$ The power of municipalities to regu-

${ }^{s}$ Collins v. P. S. C., 84 Pa. Super. 58 (Ig24), aff'g Application of Chester Auto Line, A. D. 7522 (r923), VI P. S. C. R. 477. In this case, the commission refused to issue a certificate to a second carrier to operate over a line already certified, even though the first holder had failed at the time to receive the consent of the municipality and the second carrier had obtained such consent.

In In re Lehigh Valley Transportation Company, A. D. IIg67 (1925), Pa. P. S. C. No. 1520, the Commission refused to qualify a certificate issued for the incorporation of a bus line within a municipality so as to give the municipality "regulatory supervision" over the line. The request was apparently for complete control, rather than merely regulatory power which it already had.

The phrase "within the Commonwealth" in Article I, Section I of the Act was evidently used to distinguish between intrastate and interstate rather than to limit the jurisdiction of the Commission to intercity operation. Scranton $R$. R. v. Fiorussi, $66 \mathrm{~Pa}$. Super. 475 (1917).

${ }^{35}$ Act of 1915, P. L. 685 \& I,. PA. STAт. (I920) § 297 I: "Each city may regulate the transportation by motor vehicles (not operated on tracks) of passengers or property, for pay, within the limits of the city, or from points in the city to points beyond the limits of the city. In such regulation the city may impose reasonable license fees, make regulations for the operation of vehicles, the rates to be charged for transportation and may designate certain streets upon which such vehicles, if operated, must be operated."

Municipalities of the third class have the following power under Act of I913, P. L. 568, Art. V, \& 3, Cl. 27, PA. STat. (I920) § 42I4: "Cities of the third class are authorized to establish stands for coaches, cabs, omnibuses, carriages, wagons, automobiles, and other vehicles for hire, and to enforce the observance and use thereof; and to fix the rates and prices for transportation of persons and property from one part of the city to another."

Municipalities of the third class are empowered to establish stands and fix rates for vehicles for hire within the city limits, under Act of IgI3, P. L. 568, Art. V, \& 3, PA. STAT. (Ig20) \& 4214. And under Act of 1925, P. L. 254 \& 28, PA. STAT. Supp. (I925) \& 993, they can establish safety zones, parking hours, etc., and can designate certain streets upon which such vehicles may operate, with power to impose penalties for violations of such regulations. 
late traffic, ${ }^{3,6}$ to require bonds for loss of life or injury to person or property, ${ }^{37}$ and to license vehicles and drivers, ${ }^{38}$ is obvious, although there are certain limitations on this power. "Regulation is not to be carried to the extent of prohibition." 39 The regulations cannot be inconsistent with the direct provisions of the $M O$ tor Vehicle Law, ${ }^{40}$ and they cannot be unreasonable or discriminatory. ${ }^{41}$

True it is that the.statutory powers delegated to municipalities and those delegated to the Commission are not inconsistent so as to effect a repeal by implication. ${ }^{42}$ But which is predominant, if municipality and Commission should attempt to regulate certain carriers in inconsistent manners within the broad field

None of these acts, however, provide expressly for municipal regulation of carriers operating through a municipality from one point outside it to another point also outside. There should, however, be little difficulty in interpreting the words of the acts to include operation to, from, and through a municipality.

${ }^{30}$ City of Easton v. Miller, $265 \mathrm{~Pa} .25,108 \mathrm{Atl} .262$ (1919), (routing of street railways).

${ }^{27}$ Jitney Bus Ass'n of Wilkes-Barre v. Wilkes-Barre, $256 \mathrm{~Pa}$. 462, 100 Atl. 954 (I9I7).

${ }^{23}$ Brazier v. Phila., 2I5 Pa. 297, 64 Atl. 508 (1906). In this case it was held that state provisions on the same subject do not deprive municipalities of the power to license vehicles and drivers.

${ }^{3}$ Jitney Bus Ass'n of Wilkes-Barre v. Wilkes-Barre, supra note 37. See also, Collins v. P. S. C., supra note 34 .

${ }^{10}$ See note 35 supra. The following sections in PA. Stat. (I920) and supplements thereto include all state enactments concerning motor vehicles: $\$ \S 964$ through 1020; 297I: 4214; 7683; II46I; II 462; I3289; I9043; I9043a; 19050; 29636; Act of February 19, 1926, P. L. $16 \& 5$; Act of February 19, 1926, P. L. 27 I.

"An ordinance requiring bonds of jitneys for damage by loss of life or injury to persons or property was held unreasonable in requiring a surety company to sign, imposing liability on the surety even after recovery of a loss against him, and requiring the carrying of firemen and policemen free under certain conditions. Jitney Bus Ass'n of Wilkes-Barre v. Wilkes-Barre, supra note 37. "The general regulations which it adopts must be reasonable, not unduly burdensome, and they must be uniformly applicable to all who operate under like conditions." Collins v. P. S. C., supra note 34 .

- The Act of June I, 'rgr5, giving municipalities power over motor vehicles is not inconsistent with and does not repeal the Public Service Company Law. Scranton R. R. v. Fiorussi, supra note 34; So. Pa. Traction Co. v. Kane, supra note 23. To the effect that the Public Service Company Law does not deprive municipalities of the power to regulate traffic on the streets so far at least as street railways are concerned, see City of Easton v. Miller, supra note 36 . Despite the power of the commission to issue certificates of public convenience for the operation of motor buses over roads which embrace an inter-county bridge, the authorities charged with the care of the highways may close them temporarily to make repairs on the bridge without the permission of the commission. Miller v. Johnson, 30 Pa. D. R. 359 (I92I). 
wherein both have been delegated power? In Setzer v. City of Pottsville, ${ }^{43}$ the Commission issued a certificate of public convenience authorizing a motor bus line to operate between two municipalities including a designated route within the limits of one of them. Subsequent to the granting of the certificate the latter municipality passed an ordinance designating the streets on which interurban buses could operate and forbidding operation on other streets. Under the terms of the ordinance the bus line would have been forced to change the route specified in its certificate. The operator sought to enjoin enforcement of the ordinance, but this relief was denied him. It was contended that, under the Public Service Company Law of I9I3, the authority of the Commission was superior to any ordinance the municipality might pass in contravention thereof. But the court pointed to the Act of $19 I 5,{ }^{44}$ which delegated to the city the right to impose license fees, make regulations, fix rates and designate streets upon which vehicles could operate. It said that because this statute was enacted subsequent to the Public Service Company Law it would repeal that law in so far as it would be in conflict therewith. It said, however, that the two acts could very well be construed together. Justice Porter in his opinion said:

"No individual or company has the right to operate, as a common carrier, a motor vehicle for the transportation of persons or property, without first obtaining from the Public Service Commission a certificate of public convenience, but the authority to designate the routes over which such motor vehicles shall operate is by Act of I9I5 vested in the city. The Public Service Company Law did not make the municipalities public service companies, and cities and boroughs, acting strictly as such, are unaffected by it in the exercise of their functions and powers and in the performance of their municipal duties. . . . The Act of 2915 conferred upon cities power to pass ordinances of a specific and defined character, to 'designate certain streets upon which such vehicles, if operated, must be operated.' When the legislative grant is of this specific character an ordinance passed pursuant thereto cannot be impeached as invalid because it

${ }^{43} 73 \mathrm{~Pa}$. Super. 573 (1920).

"Act of I9I5, P. L. 685, PA. Stat. (I920) § 297 I. 
would have been regarded as unreasonable if passed under the incidental power of the municipality, or under a grant of power general in its nature."

This opinion might be construed to mean that the general regulatory powers of the Commission terminate at the limits of the municipality. Such an interpretation would, however, be disastrous to the state-wide control of motor buses by the Commission. It would seem that in such matters as fixation of fares, prescribing rates, requirements of equipment and the like, a municipal ordinance is superior to the order of the Commission in so far as operation within the municipality is concerned. The Commission, however, should be construed to still have power within the municipal limits so long as the exercise thereof does not conflict with proper. municipal requirements. And further, there should be a limitation on the regulatory power of the municipality. It should not be permitted to exercise its regulatory functions in such a manner as to unreasonably impede the operation of motor carriers certified by the Commission. In such a way, there may be effected a compromise between the exercise of regulatory power by the municipality and the state agency. A similar adjustment has been arrived at in Ohio which had a somewhat more difficult problem of construing a "home rule" provision of its constitution and a statute delegating power to its public utility commission. ${ }^{45}$

Article III, Section 2 (b), of the Public Service Company Law, which makes it unlawful for any motor carrier, without first obtaining a certificate from the Commission, "to begin

4s Perrysville et al. v. Ridgeway et al., 108 Ohio 245, I40 N. E. 595 (1923); Murphy v. City of Toledo, 108 Ohio 342, I40 N. E. 626 (1923); Lorrain Street Railway v. Public Utility Commission, Ir3 Ohio 68, I48 N. 'E. 577 (1925); City of Nelsonville v. Ramsey et al., II3 Ohio 217, I48 N. E. 694 (1925); ". if the municipality does not interfere with the general powers of the Public Utilities Commission, it may, by suitable police regulations, .control, direct, and manage its streets, and the traffic thereon, and the conclusion reached is that their ordinances are not an unreasonable local police regulation relating to traffic, reciting as they do that it is intended to make the streets less congested and less dangerous to pedestrians and the public generally, and may be so enforced as not to materially lessen the efficiency of the utility. Of course, under the guise of so regulating traffic, a city may not materially interfere with the general efficiency of the utility authorized by the Public Utilities Commission within its jurisdiction." Lorrain Street Ry. v. P. U. C., supra at 69. 
the exercise of any right, power, franchise or privilege . . " 46 has beer construed to extend the regulatory powers of the Commission only over motor carriers starting operation after the effective date of the Act. Motor carriers engaged in law ful operation prior to January I, I9I4, need not obtain a certificate from the Commission. ${ }^{47}$ The effect of such a construction is to read into the act a "grandfather clause," such as is found in the laws of many of the states and which permits operation of existing motor carriers upon obtaining a certificate issued as a matter of right upon affidavit. Under the Pennsylvania $A c t$, however, motor carriers which were operating prior to passage of the Act are entirely exempt from the necessity of obtaining certificates. Operation by a motor carrier prior to the effective date of the $A c t$ confers on such carrier only the right to operate in the same class of service engaged in prior to the $A c t{ }^{48}$ In an early case it was held that such a prior operating carrier need not obtain the permission of the Commission to increase his business by adding buses or extending routes. ${ }^{49}$ There seems, however, to be no basis for such a holding. A carrier. who wishes to extend his route or increase his service is to all intents and purposes in the same position as a carrier who wishes to commence operation and should be required to obtain a certificate for the increase of business. Such has been the holding of later cases decided by the Commission. ${ }^{50}$ Its general regulatory powers, other than the issuance of

${ }^{40}$ Supra note 40. Article IV, § I2 of the Law reads: "Every public service company shall be entitled to the full enjoyment and exercise of all and every right, power and privilege which it lawfully possesses, or might possess, at the time of the "passage of this act, except as herein otherwise expressly provided. . . ."

"Wilkes-Barre Ry. v. Pugh, C. D. 592 (IgI8), III Pa. P. S. C. R. 292; Same v. Hartman, supra note 28.

${ }^{48}$ Wilkes-Barre Ry. v. Hartman, supra note 28 ; Henneous v. Flaugh \& Flaugh, C. D. 5841 (I924), VI P. S. C. R. 788.

${ }^{\omega}$ Wilkes-Barre Ry. v. Pugh, supra note 47.

${ }^{50}$ Wilkes-Barre Ry. v. Hartman, C. D. 5389 (1923), VI Pa. P. S. C. R. 362 ; The Emerick Motor Bus Line v. Harry Dan.et al., C. D. 5267 et al. (I923), VI Pa. P. S. C. R. 3I2 ; Wilkes-Barre Ry. v. Hartman, supra note 28; In re Application of G. A. Lageman, A. D. 5726 et al. (I922), V Pa. P. S. C. R. 849. The commission allowed certain certificates to issue, but stated "it must not be understood that we are giving assent to the contention that an applicant can tack his service to that of his predecessors and thereby establish a continuous service antedating the enactment of the Public Service Company Law, and thus exempt him from its provisions." 
certificates, also apply to motor carriers in operation prior to the effective date of the $A c t .{ }^{51}$

Prior to the recent United States Supreme Court decisions denying the right of the state to withhold a certificate of convenience from a motor carrier operating in interstate commerce, ${ }^{52}$ the Pennsylvania Commission had required interstate motor carriers to apply for certificates. ${ }^{53}$ It was felt that, since motor transportation was principally over short routes, it was local in its nature, falling within the class of interstate commerce which might more properly be left to the regulatory control of the state, and, in the absence of federal legislation, might be regulated by the state. But after the pronouncements of the United States Supreme Court in the Buck and Duke cases, ${ }^{54}$ the Commission completely reversed itself and held that it had no jurisdiction to require motor carriers engaged exclusively in interstate commerce to obtain a certificate. ${ }^{55}$ It probably went too far in this volte face; it could have continued to issue certificates provided it denied none to interstate carriers because their operation was inconsistent with public convenience and necessity. It would then be easier for it to exercise the "police" jurisdiction which it still

The Emerick Motor Bus Line, Inc., v. Dan, supra note 50. "The Commission may refuse to issue a certificate or it may limit the number of certificates granted as it deems to be just and proper. It may also restrict within reasonable limits the territory in which certificate holders shall operate. We are of the opinion that these principles attached to common carriers who were operating before the enactment of the Public Service Company Law as well as to those who have applied for and been granted certificates of public convenience since the effective date of our organic act. The public accommodation and convenience are the ends to be attained and the service, whether rendered under the exemption of the law or under the authority of a certificate of public convenience, is to be supervised and regulated by the Commission so as to best meet those ends."

${ }^{20}$ Infra note 54.

${ }^{5 s}$ Chambersburg, Greencastle, etc., Co. v. Hardman, C. D. 3778 (192I), V Pa. P. S. C. R. 58; So. Pa. Traction Co. v. Kane, Jr., stupra note 23; Application of Solt, A. D. I0209 (1924), VI Pa. P. S. C. R. 786; Application of Phillips et al., A. D. 7805 et al. (I924), VI Pa. P. S. C. R. 825 .

Michigan Public Utility Co. v. Duke, 266 U. S. 570 (I925) ; Buck v. Kuykendall, 267 U. S. 307 (1925).

${ }^{85}$ In re Application of E. H. Scott Transportation Co., A. D. I1515 (1925), P. S. C. No. I536; Pa. R. R. v. East Coast Coach Co., C. D. 6367 (I925), P. S. C. No. 1543 . 
retains over interstate carriers, such as definition of routes, limitation of speed and regulation of equipment. ${ }^{56}$

In issuing a certificate for the operation of a motor carrier the Commission must find that the public convenience requires its operation or incorporation, and that the granting of an application of a certificate "is necessary or proper for the service, accommodation, convenience, or safety of the public." 57 A certain well-defined practice has sprung up in. such determinations. ${ }^{58}$ The Commission has repeatedly held that where existing facilities are adequate and serve the needs of the public and the addition of motor transportation facilities would cause interference with the operation of established carriers, no certificate should issue. Many of the cases have involved jitneys or motor bus routes wishing to operate in direct competition with established street railways. The commission has consistently refused to approve such applications for a certificate. ${ }^{59}$ Where, however, the pur-

${ }^{54}$ For a discussion of the power of the state over intrastate motor carriage, see Rosenbaum \& Lilienthal, Motor Carrier. Regulation: Federal, State atd Municipal, 26 CoLUMBIA L. REv. 954 (I926). The requirement of vehicle registration and driver license applies to interstate carriers. See note 94 infra. For a recent case discussing the power of the state to require a tax on interstate motor carriers according to mileage within the state see Interstate Busses Corporation v. Blodgett, U. S. Dist. Ct. of Conn., decided January, I927.

${ }^{57}$ Article V, \& I8, P. S. C. Law, supra note Io.

${ }^{48}$ For a general discussion of the law involving the issuance of certificates of convenience and necessity, see Lillienthal and Rosenbaum, Motor Carrier Regulation by Certificates of Necessity and Convenience, 36 Yale L. J. I63 (1926).

${ }^{\circ}$ In re Application of Samuel Leysock et al., A. D. 3633 through 3637 (I920), IV Pa. P. S. C. R. 809; In re Application of the Commonwealth Transportation Company, A. D. 3270 (I920), IV Pa. P. S. C. R. 578: "The time may come, although not now apparent, when auto-bus service will be substituted for the service now furnished by the street railways, but the Commission is far from being convinced that the public is ready to accept the change or to choose auto-bus as the better agent of the two to most efficiently and conveniently serve them. The Commission is convinced, however, that the public can not for long have both services under the facts and circumstances disclosed in this case." Southern Ohio Traction Co. v. Hartel, C. D. II63, A. D. 699 (1916), II Pa. P. S. C. R. 937: "Auto-buses can be made a convenient method of transportation and would accommodate the public in many cases. It would be useful where there is no trolley operated or where it can be made an auxiliary of a trolley system." In this case a certificate was denied. Houser, Trading as Butler Transfer Co., A. D. 4183 (I920), V Pa. P. S. C. R. I22; Application of Scott, A. D. 5788 (Ig22), VI Pa. P. S. C. R. 577; Application of Roth, A. D. 7465 (I922), VI Pa. P. S. C. R. 236; Application of The Erie Motor Transit Co., A. D. 383I (1920), V Pa. P. S. C. R. 9. Competition with interurbans: Applications of George R. Houser, A. D. 5 I08 (I92I), V Pa. P. S. C. R. 594; Application of Thomas H. Quinn, A. D. 5588 (192I), V Pa. P. S. C. R. 666; Application of R. F. Budinger, A. D. 5483 (I92I), V Pa. P. S. C. R. 73 I. 
pose of the company is to render service auxiliary or supplementary to an existing street railway or railroad the certificate is ordinarily issued. ${ }^{60}$ The Commission's preference toward issuing a certificate to an established railway carrier for the operation of motor vehicles does not, however, apply where the route in question is not auxiliary or complementary to the railway service; and particularly where another motor carrier is already operating over the route in an efficient manner. ${ }^{61}$

The policy of refusing to permit motor carrier competition to place existing carriers at an undue disadvantage applies to passenger ${ }^{62}$ and freight service by railroad. ${ }^{63}$ The Commission,

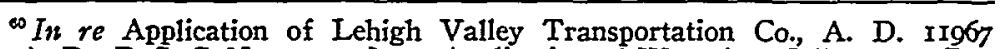
(I925), Pa. P. S, C. No. I520; Iss re Application of Wyoming Valley Auto-Bus Co., A. D. 7905 (1925), Pa. P. S. C. No. 1513; In re Application of Lawrence C. Hartman, A. D. II368 (1925), Pa. P. S. C. No. 1513; Application of Scott, A. D. I0209 (1924), VI Pa. P. S. C. R. 786, where an applicant first was refused a certificate to carry freight by motor truck because of competition with a railway company and later entered into a contract with the same company to supplement their service with his motor trucks, a certificate thereupon issued; Applications of George J. Rutledge et al., A. D. 7746, 9364, 9545, 9703, 10095 (1924), VI Pa. P.S. C. R. 820; Application of the Lehigh Transportation Co., A. D. I1967 (I925), Pa. P. S. C. No. I520. Auto-bus service by a subsidiary corporation of a street railway system is preferable to "transitory and unstable" jitney service of a large number of operators: Application of The So. Pa. Bus Co., A. D. 6720 (1922), V Pa. P. S. C. R. 930.

${ }^{67}$ Application of Ely, A. D. I1769 (1925), P. S. C. No. I512.

application of John A. Allio and George F. Allio Co., partners, A. D. $794 \mathrm{I}$ (Ig23), VI Pa. P. S. C. R. 463; In re Application of Howard V. Brown, A. D. II793 (1925), Pa. P. S. C. R. 1518; Application of Anderson Hardware Bus Line, A. D. 7506-1922 (I923), VI Pa. P. S. C. R. I84, 187, 188. "It may be that the time will come when auto buses can take the place of rail carriers, but certainly that will not be until the financial ability, stability and permanency of auto bus companies are more fully assured than at the present." Application of John A. Allio, supra. In Application of Roy Welker, A. D. 7 I21-22 (1922), VI Pa. P. S. C. R. I34, a certificate was denied a motor carrier which wished to establish "through service" even though service between some of the intervening points might afford public convenience.

${ }^{6}$ Application of Eichelberger, A. D. 4524 (I02I), V Pa. P. S. C. R. 303; Application of Bingaman Motor Express Co., A. D. 9092 (I924), VI Pa. P. S. C. R. 650, 652, 653: "It has been the policy of the Commission to refuse to permit competition with existing utilities which have large investments and are necessary for public convenience, if their service is or can be made reasonably adequate. No transportation agency can render perfect service at all times to all persons. The Commission must consider the benefit to the general public. The use of motor trucks for transporting property has reduced considerably the receipts of railroad and electric railway companies. Although such motor service may be more convenient to some shippers than service by electric railway or railroad, consideration of public convenience will not permit the Commission to take action which will endanger the continued financial stability of such established roads."

Application of G. A. Lageman, supra note 50: "It may be conceded that these wagon and truck carriers of property furnish a more adequate and 
however, will consider the reasonableness of competition by automobile with rail carriers according to the facts in each case, ${ }^{64}$ and since it is not not the object of the public utility law to establish a monopoly, but rather to see that no ultimate injury is practiced upon the public by unrestricted competition, the courts will not hold the Commission to a rigid rule. ${ }^{65}$ The issuance of a certificate to a motor carrier paralleling a traction company where operation would not seriously affect the finances of the traction company, would relieve the rush hours and might better serve certain persons, was upheld. ${ }^{66}$ Similarly, if a railroad does not

more convenient local service of a limited character than is furnished by either the railroads or the express company protesting their application. But this does not warrant the establishment of a competitive situation in isolated localities which threatens the existence of not only a State, but a Nation-wide transportation system which either is or can be made to furnish reasonably adequate and convenient service."

M. I. O'Boyle \& Henry W. Knowlton, A. D. 9238-9239 (I923), VI Pa. P. S. C. R. 555; Application of Springer \& Wolf, A. D. 9016 (I923), VI Pa. P. S. C. R. 525: "While there is undoubtedly a growing place for auto-truck service in transportation fields, the Commission is firmly of the opinion that such a place is not to be found in long distance hauling in destructive competition with established rail carriers. . . Nevertheless the allegations made are fairly illustrative of some of the conditions encountered in submitting the public to service relations with irresponsible auto-truck operators."

Application of Scott, supra note 59 at 579: "There is ample room for a remunerative auto-bus and auto-truck service without entering into injurious competition with an established trolley or steam road which is furnishing a reasonably adequate service. By co-ordinating the two methods of transportation, each carrier serving a field not already occupied by the other, both carriers, as well as the public, would be benefited thereby."

Application of Philips, supra note 53: "Within the past decade, and more particularly since the period of abnormal industrial expansion during the World War, there has been a large development in the use of motor facilities for the transportation of freight and express. The overstrain that was placed upon the rail carriers during the war period, especially in the transportation of merchandise between ports on the Atlantic Seaboard, brought into being a large number of motor concerns transporting merchandise previously shipped by rail. . . . Motor trucks were the only available means by which they could adjust themselves to the new requirements of business. By the use of trucks the factories were not only able to save crating and other shipping charges because uncrated goods could be loaded at the factory door and delivered in like condition at the store doors of consumers."

" In re Application of Alvin R. Bush, supra note 22. The Commission allowed an auto-bus and freight service to compete with railroads furnishing similar service where the business was established by wagon or motor truck for fifty years: Application of G. A. Lageman, supra hote 50.

${ }^{65}$ Pottsville Union Traction Co. v. P...S. C. (Mayer's Application), $67 \mathrm{~Pa}$. Super. 297 (I9I7) ; Same (Brady's Application), 67 Pa. Super. 304 (I9I7).

es Ibid. For a similar case where a certificate issued and the schedule of a motor carrier was limited to times when a competing railroad did not operate passenger trains, see Application of R. M. Kishback, A. D. 5645 (I92I), VI Pa. P. S. C. R. I29. 
furnish adequate service, ${ }^{67}$ or is unable to furnish the particular service contemplated by the motor carrier, such as the collection and transportation of milk and dairy products, a certificate will be granted to a competing motor carrier. ${ }^{68}$ In one case, a certificate of convenience was issued to a motor bus company to operate in competition with a steam railroad where the public would be greatly accommodated thereby; but the schedule was so arranged as to prevent competition with scheduled passenger service. ${ }^{69}$

The existence of motor carrier facilities on a route applied for is a factor to be considered where application is made for the issuance of another certificate for that same route. If the protestant to the issuance of a certificate is a motor carrier who, in operating over the route, has violated the rules of the Commission or failed to furnish adequate service, the existence of his operation will be given little weight in judging public convenience. ${ }^{\mathbf{7 0}}$ On the other hand, the Commission has said that where a territory is adequately served by existing motor carriers, it will not create a more intensive competition by allowing another motor carrier to enter the field simply because the rates of existing companies are too high, the manner of the operator discourteous, or service otherwise unsatisfactory. Appropriate relief may be had by seeking by proper action cancellation of the certificate or correction of the faulty condition. ${ }^{71}$ But where it appears from the evidence I523.

or In re Application of Fred X. Bowman, A. D. 10325 (1925), P. S. C. No.

${ }_{\text {es }}$ Application of Wilbert H. Hamilton, A. D. 4578 (I921), V Pa. P. S. C. R. 304. Application of D. M. Pearce, A. D. 7172 (1922), VI Pa. P. S. C. R. I27. In Application of Bingaman Motor Express Co., sipra note 63, a certificate was denied motor trucks operating in competition with railroads, but it was suggested that a certificate would issue for the limited purpose of carrying silk and silk products in the Reading district, because this service was not being adequately handled by the railroads. In Application of D. M. Pearce, supra at I28, it was said: "That a truck service would better accommodate and be more convenient for a few persons is not sufficient to disrupt an established and reasonably adequate and convenient general service which would be rendered less efficient by such competition."

${ }^{\infty}$ Application of The Cambria Bus Co., A. D. 5902 (1922), V Pa. P. S. C. R. 794. For a case where a certificate was allowed a bus company in competition with a street railway, see Application of Montgomery Bus Co., A. D. 5493-2I (1922), V Pa. P. S. C. R. 643.

${ }^{80}$ Lehigh Traction Co. v. Forley, C. D. 1592, A. D. 1433 (1917), III Pa. P. S. C. R. 35 I. I35.

${ }^{\pi}$ Application of Jacob Schrier, A. D. 7424-1922 (I923), VI Pa. P. S. C. R. 
that competitive service is necessary for the accommodation of the public, the Commission will allow two companies to operate over the same route, even though the competing companies may suffer somewhat thereby. ${ }^{72}$

Where several applicants are applying for the same route the Commission may exercise its discretion and attempt to select the carrier best equipped and best fitted to render service to the public. ${ }^{73}$ One of the numerous factors which may go to make one applicant preferable to the other is that the one will furnish through service in connection with another route operated by it, while the other will serve only part of the through route and necessitate the transferring from one vehicle to another. ${ }^{74}$

The policy of restricting competition, however, has not been generally applied to motor carriers operating for call and demand service. It has been felt that a certain amount of competition between such carriers is advantageous to the public. But a limit is reached even for such service, and where the Commission has felt that the service was not adequately rendered by the already authorized carriers for call and demand, it has refused to issue added certificates. ${ }^{75}$

In judging the qualification of an applicant the Commission must necessarily have wide discretion, which, however, must not be abused. An applicant which has, by its testimony, disclosed to the Commission "utter and definite disregard for constituted authority" has been denied a certificate. ${ }^{76}$ The Commission has said that the fact that an applicant has continued to operate in defiance of the law and an order of the Commission denying it a certificate on a former application "might well raise question of its fitness to a certificate." 77 An application will also be denied

\footnotetext{
${ }^{72}$ Red Arrow Bus Line v. Southern Pa. Bus Co., C. D. 6377 (1925), P. S. C. No. I526.

${ }^{73}$ Application of Rutledge, supra note 60.

"Application of Phillipsburg Motor Bus Co. et al., A. D. 9222, 9329 (1924), VI Pa. P. S. C. R. 64I.

${ }^{73}$ In re Application of Penn. Taxi Co., A. D. Irgro (ig25), P. S. C. No. I556; In re Application of the City of Chester et al., A. D. I2204 through I2334 (I925), P. S. C. No. 1533.

C. R. 623 .

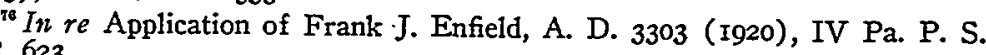

${ }^{\pi}$ Application of George R. Houser, supra note 59.
} 
where the Commisssion finds that the applicant is restricted by his charter from the furnishing of the service applied for. Thus where a taxicab company was restricted by its charter to the furnishing of taxi service, the application by the company to render group or party service was refused. ${ }^{78}$ The Commission has, however, asserted the power of making such amendments, as of routes specified in a charter, without a formal amendment of the charter, where the change is for the service, accommodation and convenience of the public. ${ }^{79}$

The power to issue certificates necessarily includes the power to limit the character and amount of service rendered under them. Otherwise, the attempted surveillance of the Commission over conditions of traffic would be futile. If a certificate were a mere unlimited permit allowing service of any kind or amount, then there is no reason for the weighty considerations of public convenience and necessity in its issuance. There is no assurance that the service originally needed to meet public convenience and necessity will not, by curtailment thereof or by increase in the demands of the community, be converted into public disadvantage. The rules of the Commission prescribe that operation under a certificate must be "limited to a route, when specified, and to the number of cars, particularly to each automobile or auto bus designated in the certificate." 80 It often exercises this power by limiting or conditioning a certificate. ${ }^{81}$ It has limited its approval of operation by designating points for operation and forbiddng serv-

${ }^{78}$ In re Application of Packard Auto Taxi Co., A. D. 7542 (I926), P. S. C. No, 1682 .

70 Application of Philadelphia Suburban Transit Co., A. D. I218I (I926), P. S. C. No. I666.

${ }^{80}$ RuLES AND REgulations, referring to the issuançe of certificates of public convenience for taxi cabs, jitneys, auto-buses, etc., $\mathrm{Pa}$. P. S. C. General Order No. I8, Adopted October 2I, I92I, Rule I. Applied in Harley v. Johnstown \& Dunlo Bus Co., C. D. 4880 (1922), V Pa. P. S. C. R. 803. Rule 5 provides: "Persons holding such certificates shall not carry more passengers in any car than the number specified for said car in the certificate."

${ }^{81}$ Application of John Beville, A. D. 7732 (I923), VI Pa. P. S. C. R. 210, where service was limited to non-competitive territory. See dissenting opinion of Commissioner Rilling at 2r3. Application of D. M. Pearce, supra note 68. (Certificate limited to gathering up and delivering milk.) 
ice to intermediate points ; ${ }^{82}$ it has granted a certificate for operation between two boroughsand denied the carrier the right to solicit or carry local passengers within the limits of one of the boroughs. ${ }^{83}$ In the absence of limitation, however, a certificate for operation between fixed termini, and through certain villages authorizes the furnishing of service to the villages named in the route $^{84}$ The Commission has also power to designate the class of motor service the certificate holder shall render. Thus it may limit a certificate to the furnishing of call and demand service, and such limitation will prohibit the furnishing of schedule service by the carrier. ${ }^{85}$

These certificates are valid for a limited time only. However, there is ample provision for renewal upon the expiration of that period. It is provided by the rules of the Commission that

"all certificates of public convenience issued for taxi-cabs, jitneys, and similar common carriers, shall hereafter be issued for a period not exceeding two years, from the following day of issuance for calendar periods beginning June I to be renewable upon application." 86

This section undoubtedly applies to certificates of all types of motor carriers. It limits their possible life to two years and requires an application for a renewal at the end of such time. Or-

${ }^{82}$ Applications of Flough and Henneous, 9370-94I4 (I924), VI Pa. P. S. C. R. 784. In this case, the contention was made that the Commission had simply the power to issue general and unrestricted certificates, under which certificate holders would have the right to operate between all points in a specified territory. It was said that the Commission did not have power to limit certificates to service between designated terminal points. The contention was overruled.

83 In re Application of E. R. Edwards et al., A. D. 2105 (I9I8), III Pa. P. S. C. R. 924 .

Lehigh Traction Co. R. v. Collins, C. D. 6078 (1926), P. S. C. No. I698.

${ }^{8}$ In re Application of Charles Krona, A. D. rog4I (Ig25), P. S. C. No. I521; West Ridge Transportation Co. v. Krona, C. D. 6r53 (I925), P. S. C. No. I522; Application of F. W. Simpson, A. D. 6819 (1922), VI Pa. P. S. C. R. 75. The Commission now ordinarily limits certificates for call and demand service to the operation of vehicles which do not accommodate more than seven passengers. Certificates issued without such limitation, however, may operate buses of any size to furnish service. Fullington Auto Bus Co. v. Grazier, C. D. 6368 (I925), P. S. C. No. I535. Group transportation was classified by the Commission as "local group or party service" instead of "sightseeing service." In re Application of Samuel .W. Eckroth, A. D. 12546 (1925), P. S. C. No. I582.

${ }^{86}$ Rule 6, Rules and Regulations, supra note 80. 
dinarily such a renewal will be allowed where the applicant is able and willing to continue service and has in the past rendered adequate service in a lawful manner. ${ }^{87}$ Where, however, certificates have been issued in the past without limitation in their terms for a specified time, such certificates need not be renewed and are effective until revoked for cause. ${ }^{88}$

It is provided by the rules of the Commission that certificates are non-transferable. Thus, where a partnership holding a certificate has dissolved, one of its members can not continue to operate as a partnership on the route covered. ${ }^{89}$ An amendment of a certificate, however, may be allowed, so as to substitute the one member for the partnership. It has allowed such an amendment upon condition that the individual member file a bond and take out indemnity insurance in his individual name. ${ }^{90}$

It is prescribed by Rule Io of the General Rules and Regulations that:

"The Commission will require all applicants and holders of certificates to show either financial responsibility or the protection of liability and indemnity insurance, the amount of insurance to be fixed in each case according to the judgment of the Commission."

It may thus be seen that it will in each case exercise its judgment as to whether insurance is necessary or not and the amount needed. And in addition to this there is another regulatory requirement, viz., that only motor vehicles licensed by the State Highway Department and only drivers licensed by that department shall be included in the certificate, ${ }^{01}$ and that the license number of vehicles be duly filed. ${ }^{22}$ It will, for failure of a motor I5II.

${ }^{2}$ In re Application of George R. Arner, A. D. I0797 (1925), P. S. C. No.

${ }^{8}$ Pittsburgh Trans. Co. et al. v. American Taxi Cab Co. et al., C. D. 6468, 6469 (1925), P. S. C. No. 1588.

* Scranton, Montrose \& Binghamton R. R. v. Trail Express Co., C. D. 5359 (1923), VI Pa. P. S. C. R. I50.

${ }^{\circ}$ P. S. C. v. Allen et al., C. D. 3I72 (I9I8), IV Pa. P. S. C. R. 477.

${ }^{21}$ Rule 7, Rules and Regulations, supra note 80; Scranton R. R. v. Walsh, supra note 13. Under Act of 1925, P. L. 254, PA. STAT. SuPP. (I925) § 972, a motor bus cannot be registered unless there is a subsisting certificate of the Commission covering it.

${ }^{92}$ Rule 8, Rules and Regulations, supra note 80. 
carrier to obtain a certificate, certify this fact to the Secretary of Highways with the request that the registration of the vehicles and the operators' licenses be revoked. ${ }^{93}$ And if a carrier has failed to have his vehicles properly registered, ${ }^{94}$ such fact will also be certified to that official.

The Commission has prescribed that a certificate may be revoked by it at any time for violation of its rules or "for any failure to operate the said cars in a safe manner." 95 Thus, it will revoke a certificate for operation contrary to the terms and conditions of the certificate. ${ }^{96}$ It will revoke a certificate for failure to operate for an extended time, for example, nine months; ${ }^{97}$ or for violation of a rule of the Commission, such as that prohibiting simulation of coloring of other cabs. ${ }^{98}$ A certificate has also been revoked for failure of the holder to appear and offer testimony in denial of allegations supporting a petition for revocation by a competing transit company. ${ }^{99}$ Change of traffic conditions since the issuance of certificate, so that operation is no longer necessary or proper for service to the public, is also ground for revocation of an outstanding certificate. ${ }^{100}$ A certificate, however, will not be revoked where the violation thereof or the violation of law relied on

${ }^{93}$ Act of 1919, P. L. 805, PA. STar. (1920) \$§ 1002-1004; Act of 1925, P. L. 254 \$ 2 ; P. S. C. v. Krona, C. D. 6506 (1925), P. S. C. No. 1583; P. S. C. v. Connoro, C. D. 6539 (1926), P. S. C. No. 1650.

${ }^{94}$ This obligation to register motor cars applies equally to interstate carriers. P. S. C. v. Russo, C. D. 6059 (1924), P. S. C. No. 1464.

${ }^{95}$ Rule 15 , supra note 80 .

McCormick v. John Louis, C. D. 6354 (I925), P. S. C. No. 1595.

${ }^{27}$ In re Application of Alfred B. Martin, A. D. II078 (I925), P. S. C. No. 1630. A certificate was issued to a taxicab company in I9I9 and did not limit the exercise of rights thereunder for the two-year period, as is the present custom. The carrier ceased operating for four years, but its certificate was never revoked. The Commission held that it would not, after the company had resumed operation, revoke the certificate for the previous failure. Pittsburgh Transp. Co. et al. v. Americus Taxi Cab Co., supra note 88.

${ }^{95}$ Yellow Cab Co. v. Campbell, C. D. 6527 (1925), P. S. C. No. 1624. See ruling of the Commission relative to simulating the color and design of cars of special design or marking operating as taxicabs, February $7,1922$. R. 89 .

${ }^{92}$ In re Application of Thomas Howard, A. D. 216 (I9I6), III Pa. P. S. C.

${ }^{100}$ Scranton R. R. v. Ownes, C. D. 442 (1915), II Pa. P. S. C. R. 269 ; Scranton R. R. v. Wilson \& Williams, C. D. 443 (I915), II Pa. P. S. C. R. 270; In re Application of Diehl, A. D. 3 I2 (I9I6), II Pa. P. S. C. R. 59I (Appealed to Superior Court and aff'd in Diehl v. P. S. C., 69 Pa. Super. 419 (rg18)). 
has been "innocent, non-intentional or in misapprehension of duties imposed by the law." 101 And even if there are adequate grounds for revocation of a certificate, it is discretionary with the Commission whether it shall exercise its power. Where unusual conditions, such as labor conditions, have affected the traffic, the Commission has exercised its discretion and refused to revoke. ${ }^{102}$ And where the public will be inconvenienced by the revocation, it has refused to revoke a certificate because of failure of the operator to confine his actions to his authorized route. ${ }^{103}$

There are several methods of proceeding against a motor carrier which is operating without a certificate. A carrier injuriously affected by the unlawful operation may bring injunctive proceedings in a court to prohibit its operation, ${ }^{104}$ or sue for damages sustained. ${ }^{105}$ It may also apply to the Commission for a desisting order, ${ }^{106}$ or an order imposing penalties. ${ }^{107}$ In addition to this the Commission may, of course, issue a desisting order of its own motion. ${ }^{108}$ This order may be enforced either in court proceedings by the Commission, ${ }^{109}$ in proceedings by the attorney-general, ${ }^{110}$ or by action for penalties. ${ }^{111}$ The Act also provides a pen-

${ }^{101}$ West. Penn. Rys. v. Capuzzi, C. D. 6676 (1925), P. S. C. No. 1628; P. S. C. v. Allen, supra note 90 ; Lehigh Traction Co. v. Collins, C. D. I591 (I918), III $\mathrm{Pa}$. P. S. C. R. I9I. It has been held that a certificate issued to a corporation will not be revoked because the stock of the corporation has been purchased by a person who has violated a Commission order where it cannot be established that the corporation iself is guilty. Pittsburgh Transfer Co. et al. v. Americus Taxi Cab Co., supra note 88.

${ }^{102}$ Emerick Motor Bus Line Co. v. Bellefonte Central Transportation Co., C. D. 27 II (1918), IV Pa. P. S. C. R. I59.

${ }^{103}$ Scranton Ry. v. Ownes, C. D. 6515 (1925), P. S. C. No. 157 I.

${ }^{104} \mathrm{~Pa}$., N. J. Ry. v. Ellin, I D. \& C. (Pa. r922) 175.

${ }^{105}$ P. S. C. Law, supra note Io, Art. VI, § 40.

${ }^{100}$ Scranton R. R. v. Walsh, supra note I3.

${ }^{107}$ P. S. C. Law, Art. VI, $\$ \$ 36,42,43$. See for example: Hagan, Inc., White Line Transfer \& Taxicab Co. v. Coldren, C. D. 4671 (1922), V Pa. P. S. C. R. 738 .

${ }^{108}$ P. S. C. Law, Art. VI, § 2.

${ }^{100}$ Ibid. Art. VI, § 33.

${ }^{110}$ Ibid. Art. VI, \& 34.

III Ibid. Art. VI, \& 35. In cases where penalties have been imposed for violation of the Commission's General Order requiring buses to stop before crossing tracks, see Lehigh Traction Co. v. Collins, C. D. 6078 (1925), P. S. C. No. I627; Pa. R. R. v. Fullington Auto Bus Co., C. D. 6525 (I925), P. S. C. No. 1577. A penalty will not be imposed where an unlawful operation was under a supposed right. Plank v. Gilbert, supra note 22. 
alty for false statements knowingly made in order to procure a certificate. $^{112}$

Aside from the issuance of certificates, the commission has, under the terms of the Public Service Company Law, general regulative powers over motor carrier companies. By virtue of this it has required that all holders of certificates file with it their schedules of rates and charges in a manner prescribed; ${ }^{113}$ and it has, in some cases, exercised its power to fix rates. In Barber et $a l . v$. Drew, ${ }^{114}$ it stated that it will not ordinarily value and fix the rates of small motor carrier companies on the same basis as it would the more pretentious utilities. In the same case, however, it sustained a complaint against the increase of fares from five to ten cents or three tickets for twenty-five cents, where it appeared that under the five-cent fare the company was earning fifty per cent. of its capital actually invested, after deduction of expenses, and fifty per cent. of depreciation from its earnings. In one case, the Commission fixed the rates for auto-bus service at ten cents cash fare and four tickets for twenty-five cents. ${ }^{115}$ In another it permitted an auto-bus company operating at a loss to discontinue weekly pass tickets which were less profitable than other forms of tickets. ${ }^{116}$ It has also assumed control over an attempted discontinuance of a service by an auto-bus company, refusing to allow, until after the trial period of newly increased rates, discontinuance

\footnotetext{
${ }^{122}$ P. S. C. Law, Art. VI, $\S 38$.

${ }^{113}$ Rule 14, supra note 80 . See also Rule I3 for posting of taxi rates inside the bodies of the vehicles.

${ }^{114}$ C. D. 3124, 3I43 (I9I8), IV Pa. P. S. C. R. 444-445. "It is not to be presumed that the Commission will, or should, attempt to regulate small autobus or other vehicular concerns under the same standards of valuation and rates of return that apply to utilities in which capital in large amount is invested by incorporated companies. Elements such as the employment of individual time and talents in the development of such businesses, and which deserve reward entirely apart from any measure of fixed return upon the meager amounts of capital invested, must be considered if these small and worthy enterprises are to be encouraged in giving the best possible public service. But it must also be considered as in the respondent's case, that such utilities are given free, excepting only a few inconsequential local assessments or taxes, exclusive rights of way over streets and highways maintained at public expense, and all the benefits of police and other protection which the State and the local communities furnish."

${ }^{115}$ In re Drew, A. D. 4305 (I92I), V Pa. P. S. C. R. 31 I. 1572 .

${ }^{116}$ Schaeffer et al. v. Citizens' Transit Co., C. D. 6415 (1925), P. S. C. No.
} 
on the ground of unprofitable operation. ${ }^{117}$ And in addition it has required the painting of the name of the company and the number of certificate on the sides of vehicles, ${ }^{118}$ the reporting of accidents, ${ }^{119}$ the equipment of taxicabs with taximeters and the posting in the cab of a schedule of rates, ${ }^{120}$ and the stopping of motor carriers at crossings of highways with steam and electric interurban railways. ${ }^{121}$

In order to obtain a certificate for the operation of a motor carrier or for incorporation of such a company it is necessary to make application to the Commission under the procedure set out in the Act. Hearings must be held, notice given, and a written finding made submitting its approval. ${ }^{122}$ Thereafter a certificate of public convenience under seal of the Commission must issue and a duplicate be duly filed among its records. ${ }^{123}$ An application for incorporation of a motor carrier company is a separate proceeding from the application for authority to commence operation of such company, and the granting of a certificate to incorporate will not authorize operation in the territory covered by the charter. A separate application for such permission must be made. ${ }^{124}$ It has been pointed out above that a carrier is limited to operation of the equipment specified in its certificate. In order to operate additional cars, including substitution or replacement I474.

${ }^{12 \pi}$ In re Application York Transit Co., A. D. 11352 (1924), P. S. C. No.

${ }^{218}$ Rule, 4, General Order No. 18, supra note 80.

${ }^{119}$ Rule II, General Order No. 18, supra note 80.

${ }^{120}$ Rules 12 and 13, General Order No. 18, supra note 80.

${ }^{22}$ General Order No. 24, requiring common carriers of passengers or property of automobiles to come to a full stop before crossing the tracks of any steam or electric interurban railway. Adopted February I4, I922.

${ }^{20}$ An application for a certificate has been denied for failure to give notice to competing carriers. Application of Mike Fazzone, A. D. 5982 (I922), V Pa. P. S. C. R. 758.

${ }^{223}$ P. S. C. Law, Art. VI, \& Ig. Where the Commission has granted a certifcate to a motor carrier it may grant an application for a rehearing based on failure of the certificate holder to give proper notice, and may, where the evidence on rehearing warrants, revoke the certificate. Diehl v. P. S. C., $69 \mathrm{~Pa}$. Super. 4I9 (IgI8). Where a complaint is filed against a motor carrier for operation without a certificate and thereafter the carrier applies for a certificate the two cases are ordinarily held together. Allegheny Valley St. Ry. v. Peter Greel, C. D. 64I, A. D. 4 I6 (rgI6), II Pa. P. S. C. R. 646 .

124 Fagan et al. v. The Pittsburgh Transportation Co., C. D. 2849 (1918), III Pa. P. S. C. R. 65 . 
thereof, it must apply to the Commission. Such application may be made under the original application docket number by petition verified by affidavit. ${ }^{125}$

The ordinary practice for the review of Commission findings and orders applies in the case of orders involving motor carriers. It will be unnecessary herein to describe fully the procedure. ${ }^{126}$ Suffice it to say that the court in reviewing the findings of the Commission, as to public convenience in the issuance of a certificate, will merely look to see if the judgment rests upon competent and relevant evidence. It will not look to the expediency or wisdom of the order nor will it weigh the evidence to determine if, on the testimony, it would make a similar ruling. ${ }^{12 \tau}$ The burden of proof in reviewing the findings of the Commission is upon the appellant. ${ }^{128}$

Irzein S. Rosenbaum.

Cincinnati, Ohio.

David E. Lilienthal.

Chicago, Ill.

${ }^{235}$ Rule 2, General Order No. 18, supra note 80.

${ }^{120}$ P. S. C. Law, Art. VI.

${ }^{27}$ Collins $e t$ al. v. P. S. C., 84 Pa. Super. 58 (1924) ; Gogaware v. P. S. C., $83 \mathrm{~Pa}$. Super. 269 (r924).

${ }^{128}$ Collins et al. v. P. S. C., supra note I27. 